\title{
Measurements of Strontium-90 in portuguese milk samples using liquid scintillation counting technique
}

\author{
I. Lopes and M.J. Madruga \\ Nuclear and Technological Institute, Radiological Protection and Safety Unit, \\ E. N. 10, Apartado 21, 2686-953 Sacavém, Portugal \\ e-mail: ilopes@itn.pt
}

\begin{abstract}
The objective of this study is the implementation of a method combining extraction chromatography and liquid scintillation counting (LSC) technique to the determination of ${ }^{90} \mathrm{Sr}$ in milk samples. The strontium separation is performed using the commercially available Sr-resin (Eichrom) and the beta counting is carried out using a liquid scintillation detector system (Tri-Carb 3170 TR/SL, Packard). Firstly, the trials are performed with $300 \mathrm{~mL}$ of milk and $0.7 \mathrm{~g}$ of resin. Validation trials are carried out using spiked milk samples with different ${ }^{90} \mathrm{Sr}$ activities and the accuracy of the methodology is also been tested with an IAEA 152 reference milk sample. The results obtained had shown good accuracy of expected value. The minimum detectable activity (MDA) obtained for a confidence level of $95 \%$ and 60 minutes of sample counting time was $0.20 \mathrm{~Bq} \mathrm{~L}^{-1}$. In order to improve the detection limits for ${ }^{90} \mathrm{Sr}, 1$ liter of milk and $3 \mathrm{~g}$ of resin were used and the MDA value in these conditions was improved to $0.012 \mathrm{BqL}^{-1}$. The method was applied to the determination of the ${ }^{90} \mathrm{Sr}$ concentrations in milk samples from different regions of Portugal.
\end{abstract}

\section{INTRODUCTION}

Strontium-90 $\left({ }^{90} \mathrm{Sr}\right)$ a pure $\beta$ emitter, generated in nuclear fission process $\left({ }^{235} \mathrm{U}\right.$ and ${ }^{239} \mathrm{Pu}$ fission reaction) was widely spread to the environment from atmospheric nuclear tests, nuclear waste discharges and from NPP accidents as Chernobyl accident. During fallout ${ }^{90} \mathrm{Sr}$ could be deposited directly on plants or transferred from soil to plants and indirectly to animals. It could be intake by man, through food chain, mainly through milk ingestion.

Since the nuclear weapons testing (years sixties) the ${ }^{90} \mathrm{Sr}$ levels in the environment have decrease and consequently, the ${ }^{90} \mathrm{Sr}$ concentrations in foodstuff have diminished considerably. Nowadays, the activity levels in milk samples are low and to reach these levels, larger volume of sample $(>1 \mathrm{~L})$ or larger counting times are required. A variety of radioanalytical procedures of ${ }^{90} \mathrm{Sr}$ determination in milk is available [1]. This kind of analysis is difficult due to the significant quantities of proteins, fats and calcium present in the samples. The calcium is difficult to remove selectively due its similar chemical behavior with strontium and can cause interferences on strontium recovery [2]. Elements, such as ${ }^{40} \mathrm{~K}$, ${ }^{137} \mathrm{Cs}$ or ${ }^{140} \mathrm{Ba}$ could interfere during the detection of strontium on beta counters, if they are extracted together with strontium. In order to minimize this interference an essential step is the separation and purification of this element from other beta emitters present in the sample, such as radionuclides from the thorium and uranium natural series and anthropogenic radionuclides $\left({ }^{137} \mathrm{Cs},{ }^{144} \mathrm{Ce},{ }^{99} \mathrm{Tc},{ }^{125} \mathrm{I}\right)[3]$.

The classical way of ${ }^{90} \mathrm{Sr}$ determination is based on the greater solubility of calcium nitrate in fuming nitric acid. This method has the disadvantage of handling large amounts of nitric acid for repeated precipitations [4]. Nowadays, this method tends to be replaced by safer and less elaborate procedures. The Sr-resin (Eichrom) was developed [5] and it has been successful applied for strontium analysis. The success of this resin is because the crown ethers have the ability to form strong complexes with alkali and alkaline earths elements. Dicyclohexano-18-crown-6 and its derivatives provide a very selective complexed environment for Sr ions. For that reason, strontium produces very strong bonds on the chromatographic column filled with the Sr-resin, which enables a rapid and simple separation 
of strontium from calcium, potassium and many other elements. The procedures using this resin are usually easier, which reflected in shorter analysis time and higher recoveries [6], however, an appropriate selection of column load (mass resin, bed length) and working conditions should be performed [7].

Environmental radioactivity survey has been undertaken by the Radiological Protection and Safety Unit (UPSR) of the Nuclear and Technological Institute (ITN) to investigate the radionuclide concentrations in various food chain components [8]. The implementation of a method combining extraction chromatography and liquid scintillation counting (LSC) technique, for the determination of

${ }^{90} \mathrm{Sr}$ in milk samples, is the aim of this work.

\section{MATERIALS AND METHODS}

The milk samples are evaporated, dried at $100{ }^{\circ} \mathrm{C}$ and burned gradually until $600^{\circ} \mathrm{C}$ in a muffle furnace to removal of the proteins and fats. The complete decomposition of organic materials is essential (the color of the residue should become white). To each sample, stable strontium carrier solution (20 mg L $\mathrm{m}^{-1}$ of $\mathrm{Sr}$ ) and ${ }^{85} \mathrm{Sr}$ tracer (Analytics Inc. USA) are added for chemical recovery.

The ash sample ( $2.5 \mathrm{~g}$, which corresponds to approximately 0.300 liter of milk) is dissolved in nitric acid $\left(\mathrm{HNO}_{3} 6 \mathrm{M}\right)$ and centrifuged. Then, oxalic acid saturated solution is added to provide a sufficiently clean separation of ${ }^{90} \mathrm{Sr}$ and to eliminate other alkaline metals (such as ${ }^{137} \mathrm{Cs}$ and ${ }^{134} \mathrm{Cs}$ ). The pH of the solution is adjusted to 4 , with ammonium solution (25\%) and the oxalate precipitate is filtered through a $0.45 \mu \mathrm{m}$ ash filter and incinerated at $800^{\circ} \mathrm{C}$.

Afterwards, the residue is dissolved with $\mathrm{HNO}_{3} 6 \mathrm{M}$ and the $\mathrm{pH}$ adjusted to 10. A precipitation is carried out with ammonium carbonate saturated solution and the resulting mixture is heated to coagulate the precipitate and to remove the excess of ammonium in solution. The residue is centrifuged, washed with distilled water and dissolved with $10 \mathrm{ml}$ of $8 \mathrm{M} \mathrm{HNO}_{3}$.

Then, the sample is passed through polypropylene pre-packed columns of $2 \mathrm{ml}(0.8 \mathrm{~cm}$ inner diameter), filled with $0.7 \mathrm{~g}$ Sr-resin (Eichrom) (particle size 100-150 $\mu \mathrm{m}$ ) pre-conditioned with $8 \mathrm{MHNO}_{3}$. The columns are rinsed with $10 \mathrm{ml}$ of $3 \mathrm{M} \mathrm{HNO}_{3}$ (to remove the elements not retained on the column). In order to avoid the quenching effects with liquid scintillation cocktail, the remaining acid is removed by rinsing the column with $1.5 \mathrm{ml}$ of distilled water. The strontium retained in the column is stripped with $8 \mathrm{ml}$ of distilled water to a glass scintillation vial (gravity provided sufficient regulation of the flow rate). As reported in literature [2] it was verified that columns could be used at least 3-4 times.

Afterwards, the strontium solution eluted is mixed with $12 \mathrm{ml}$ of cocktail (Ultima Gold LLT, Packard) and measured by LSC technique, using a low background liquid scintillation counter (TriCarb model 3170 TR/ SL, Packard). The counting efficiency was estimated with standards of ${ }^{90} \mathrm{Sr}$, prepared at different activities (1-20 Bq) from certified ${ }^{90} \mathrm{Sr}$ reference solution (Amersham). The ${ }^{85} \mathrm{Sr}$ used as tracer is measured, after the elution procedure, in the channel region of $0-10 \mathrm{keV}$. The ${ }^{90} \mathrm{Sr}$ beta activity is determined in the channel region $250-800 \mathrm{keV}$, through ${ }^{90} \mathrm{Y}$ ingrowths (after 21 days, the radioactive equilibrium between ${ }^{90} \mathrm{Sr}$ and ${ }^{90} \mathrm{Y}$, is partly reached). The background was prepared using $8 \mathrm{ml}$ of $0.05 \mathrm{M} \mathrm{HNO}_{3}$ mixed with $12 \mathrm{ml}$ of cocktail (Ultima Gold LLT, Packard) measured in the same conditions as the samples, for 60 minutes.

\section{RESULTS}

\subsection{Validation trials}

Validation trials were performed with ${ }^{90} \mathrm{Sr}$ spiked milk samples. The chemical yield of the samples processed according to the experimental conditions described above, was determined using ${ }^{85} \mathrm{Sr}$ as tracer (Table 1). The mean value obtained $(67.4 \pm 10.7 \% ; \mathrm{n}=9)$ is comparable with the value of $62 \pm 11 \%$ referred in the literature [4]. Other authors [9] consider that a chemical yield of about $60 \%$ is acceptable. 
The results of ${ }^{90} \mathrm{Sr}$ spiked milk samples analyses show good accuracy of expected values (Table 1). The mean recovery $(114.6 \pm 3.7 \% ; \mathrm{n}=6)$ was obtained with a precision of $3.2 \%$.

Table 1. Results of ${ }^{90} \mathrm{Sr}$ spiked milk samples.

\begin{tabular}{|c|c|c|c|c|c|}
\hline $\begin{array}{c}\text { Milk } \\
\text { Samples }\end{array}$ & $\begin{array}{c}\text { Chemical yield } \\
(\% \mathbf{\%} \boldsymbol{\sigma})\end{array}$ & $\begin{array}{c}{ }^{\mathbf{9 0}} \mathbf{S r} \text { added } \\
\left(\mathbf{B q ~}^{-1} \mathbf{\pm} \boldsymbol{\sigma}\right)\end{array}$ & $\begin{array}{c}{ }^{\mathbf{9 0}} \mathbf{S r} \text { measured } \\
\left(\mathbf{B q ~}^{-\mathbf{1}} \mathbf{\pm 2} \boldsymbol{\sigma}\right)\end{array}$ & $\begin{array}{c}\text { Recovery } \\
(\boldsymbol{\%} \mathbf{2} \boldsymbol{\sigma})\end{array}$ & $\begin{array}{c}\text { Deviation } \\
(\boldsymbol{\%})\end{array}$ \\
\hline 1 & $86.3 \pm 6.8$ & $0.76 \pm 0.01$ & $0.84 \pm 0.20$ & $110.5 \pm 30.1$ & 10.5 \\
\hline 2 & $82.2 \pm 6.3$ & $0.76 \pm 0.01$ & $0.91 \pm 0.22$ & $119.3 \pm 28.9$ & 19.7 \\
\hline 3 & $60.7 \pm 4.2$ & $0.69 \pm 0.01$ & $0.82 \pm 0.16$ & $118.6 \pm 23.4$ & 18.8 \\
\hline 4 & $63.6 \pm 4.6$ & $0.69 \pm 0.01$ & $0.79 \pm 0.16$ & $113.2 \pm 23.0$ & 14.5 \\
\hline 5 & $63.7 \pm 4.6$ & $0.69 \pm 0.01$ & $0.78 \pm 0.16$ & $112.6 \pm 23.2$ & 13.0 \\
\hline 6 & $53.1 \pm 3.9$ & $0.69 \pm 0.01$ & $0.77 \pm 0.15$ & $111.3 \pm 21.8$ & 11.6 \\
\hline
\end{tabular}

The methodology accuracy was also tested using a reference milk sample (IAEA-152). The reference and the measured (duplicate samples) concentration values of ${ }^{90} \mathrm{Sr}$ are presented in Table 2 . The Z-score values obtained, 1.47 and 1.38 for sample 1 and 2 respectively, are in good agreement and within the value considered acceptable (Z-score $<3$ ) by other authors [10].

Table 2. Results of IAEA-152 reference milk sample analyses.

\begin{tabular}{|c|c|c|}
\hline $\begin{array}{c}\text { Reference Milk Sample } \\
(\mathbf{I A E A - 1 5 2})\end{array}$ & $\begin{array}{c}{ }^{\mathbf{9 0}} \mathbf{S r} \text { measured }^{(\mathrm{b})} \\
\left(\mathbf{B q ~ k g}^{\mathbf{1}}\right)\end{array}$ & Z-score $^{(\mathrm{c})}$ \\
\hline 1 & $10.6 \pm 3.9$ & 1.47 \\
\hline 2 & $10.4 \pm 3.8$ & 1.38 \\
\hline Reference Value $^{(\mathrm{a})}$ & $7.7(7.0-8.3)$ & ---- \\
\hline
\end{tabular}

(a) For $95 \%$ of confidence interval level;

(b) Calculated using the mean value of the chemical yield $67.4 \pm 10.7 \%(\mathrm{n}=9)$;

(c) $\mathrm{Z}$-score $=\left[\left(\mathrm{X}_{\mathrm{exp}}-\mathrm{X}_{\mathrm{ref}}\right) /\left(\operatorname{sqrt}\left(\mu_{\mathrm{exp}}^{2}+\mu_{\mathrm{ref}}^{2}\right)\right]\right.$

$\mathrm{X}_{\text {exp }}$ is the experimental value; $\mathrm{X}_{\text {ref }}$ is the reference value;

$\mu_{\exp }$ is the uncertainty of the experimental value;

$\mathrm{U}_{\text {ref }}$ is the uncertainty of the reference material.

\subsection{Analyses of milk samples}

For a set of milk samples analyzed following this experimental protocol it was observed that the values obtained were below the minimum detectable activity (MDA). The MDA value calculated [11] for a confidence level of $95 \%$, using $2.5 \mathrm{~g}$ milk ash and 60 minutes of counting time was $0.220 \mathrm{~Bq} \mathrm{~L}^{-1}$. Therefore, in order to be able to quantify the activity of ${ }^{90} \mathrm{Sr}$ in milk it was necessary to decrease the MDA level.

Taking into account this aim, the technique was improved [12] using large quantities of sample (7 $\mathrm{g}$ of milk ash which corresponds to approximately 1 liter of milk) and Sr-resin ( $3 \mathrm{~g})$. In this case the MDA value decreased to $0.050 \mathrm{BqL}^{-1}$. Increasing the background counting time to 1220 minutes a MDA value of $0.012 \mathrm{~Bq} \mathrm{~L}^{-1}$ was achieved.

Following these experimental conditions, some milk samples were analyzed. The results obtained are presented in Table 3 . The ${ }^{90} \mathrm{Sr}$ activities vary from values lower than 0.012 to $0.048 \pm 0.016 \mathrm{~Bq} \mathrm{~L}^{-1}$. These values are of the same order of magnitude of those obtained using the fuming nitric acid method [13]. In general, the results obtained are similar with those reported to other countries. For instance, values ranging from 0.006 to $0.060 \mathrm{~Bq} \mathrm{~L}^{-1}$ and from 0.026 to $0.047 \mathrm{BqL}^{-1}$ were reported to milk samples collected in Spain [14] and Finland [15] respectively. 
Table 3. Measurements of strontium- 90 in milk samples.

\begin{tabular}{|c|c|c|}
\hline Milk Sample & $\begin{array}{c}\text { Sample ash } \\
\text { (g) }\end{array}$ & $\begin{array}{c}{ }^{\mathbf{9}} \mathbf{S r} \text { activity } \\
\left(\mathbf{B q ~ L}^{-1} \mathbf{2} \boldsymbol{\sigma}\right)\end{array}$ \\
\hline A & 7.23 & $<0.012$ \\
\hline B & 7.29 & $<0.012$ \\
\hline C & 7.01 & $0.048 \pm 0.016$ \\
\hline D & 6.95 & $0.033 \pm 0.016$ \\
\hline E & 6.58 & $0.018 \pm 0.012$ \\
\hline F & 7.69 & $0.031 \pm 0.014$ \\
\hline G & 7.22 & $0.040 \pm 0.018$ \\
\hline H & 7.24 & $0.013 \pm 0.018$ \\
\hline I & 7.15 & $0.043 \pm 0.015$ \\
\hline
\end{tabular}

\section{CONCLUSIONS}

This method is safer and less time-consuming when compared to the classical method using fuming nitric acid. The methodology accuracy was proved with validation tests performed with ${ }^{90} \mathrm{Sr}$ spiked samples and reference material.

The values of MDA achieved $\left(0.012 \mathrm{~Bq} \mathrm{~L}^{-1}\right)$ with the improvements introduced in the method, allows to quantify the levels of ${ }^{90} \mathrm{Sr}$ in the majority of the milk samples analyzed. These findings allow concluding that this methodology could be well applied to the determination of ${ }^{90} \mathrm{Sr}$ in milk samples within the environmental radioactivity survey programmes.

\section{References}

[1] Brun S., Y. Kergadallan, B. Boursier, J.-M. Fremy and F. Janin Lait 83 (2003) 1-15.

[2] Jakopič R. and L. Benedik, Acta Chim. Slov. 52 (2005) 297-302.

[3] Torres J.M., M. Llauradó, G. Rauret, M. Bickel, T. Altzitzoglou and R. Pilviö, Anal. Chim. Acta 414 (2000) 101-111.

[4] Brun S., S. Bessac, D. Uridat and B. Boursier, J. Radioanal. Nucl. Chem. 253 (2002) 191-197.

[5] Horwitz E.P., R. Chiarizia and M.L. Dietz, Solvent Extr. Ion Exch. 10(1992) 313-336.

[6] Hewitt W.J. and G. Bronislawa, Radioactivity \& Radiochemistry 5 (1994) 8-16.

[7] Grahek Ž., K. Kožutic and M. Rožmarié-Mačefat, J. Radioanal. Nucl. Chem. 268 (2006) 179-190.

[8] Madruga M.J. Applied Radiation and Isotopes, http://dx.doi.org/10.1016/j.apradiso.2008.04.008 (2008).

[9] Chobola R., P. Mell, L. Daróczi and A. Vincze, J. Radioanal. Nucl. Chem., 267 (2006) 297-304.

[10] Popov L., X. Hou, S. P. Nielson, Y. Yu, R. Djingova and I. Kuleff, J. Radioanal. Nucl. Chem., 269 (2006) 161-173.

[11] Currie L.A., Analytic Chemistry 40 (1968) 586-593.

[12] Lopes I. and Madruga M.J., in LSC 2008 Advances in Liquid Scintilation Spectrometry International Conference, Davos, Switzerland, 25-30 May 2008.

[13] Madruga M.J., A.S. Lemos and L. Machado, in Proceed. $9^{a}$ Conferência Nacional do Ambiente, Aveiro, 2007, C. Borrego et al. (Eds), Publ. Universidade de Aveiro, Portugal (ISBN: 978-972789-230-3) pp. 147.

[14] Calvo A, I. Tovar, C. Castillo, R. Collantes, A. Carmona and L. Salvador, in Programas de Vigilância Radiológica Ambiental - Resultados 2004. Colección Informes Técnicos INT-04.11, Consejo de Seguridad Nuclear, Depósito legal: M-17.978-2006 (2005).

[15] STUK-B-77, in Surveillance of Environmental Radiation in Finland. Annual Report 2006, R. Mustonen (Ed.): Radiation and Nuclear Safety Authority, Yliopistopaino, Helsinki, ISBN 978952-478-233-6 (2007). 